\title{
Child Poverty, Demographic Transition and Gender Bias in Education in India: Household Data Analysis (1993-94 and 2004-05)*
}

\author{
D.P. Chaudhri \\ Monash University
}

\author{
\& Raghbendra Jha \\ Australian National University
}

\begin{abstract}
This paper begins by highlighting some key characteristics of the demographic transition and child education and their relation to household poverty status in India as evidenced by our analysis of Census data (1951-2001) and those from NSS surveys in 1993-94 and 2004-05. Although total fertility rates have declined for the country as a whole and for all states over the last three censuses of India there is considerable variation by space, by poverty status and by education of women in the household in the two cross sections. Child poverty rates exceed those for the whole population. The number of children in the household depends on the number of women in child-bearing age and their distribution across this age group, female education and per capita monthly expenditure of households as well as by social groups. We find evidence of gender bias in education and argue that for approximately half of India's children the Right to Education Act must involve substantial improvements in the quality of education to be meaningful and reflect the spirit of the RTE law.
\end{abstract}

Keywords: Gender Bias in Education, Census, National Sample Survey, Demographic Transition, India

JEL Classification Code: J16, N35, O15, O53

Address all correspondence to: Prof. Raghbendra Jha, ASARC, Arndt-Corden Dept of Economics, H.C. Coombs Building (09) Australian National University, Canberra, ACT 0200, Australia Phone: + 6126125 2683, Fax: + 6126125 0443, Email: r.jha@anu.edu.au

\footnotetext{
${ }^{*}$ We are grateful to Hai Anh La for competent research assistance. The usual disclaimer applies.
} 


\section{Child poverty, Demographic Transition and Gender Bias in Education in India: Household Data Analysis (1993-04 and 2004-05)}

\section{Introduction}

Two decades of economic reforms in India since 1991 had a major impact on economic prosperity of a majority of households and also on participation of their children in elementary education. Demographic transition also accelerated during this period but the pace and pattern of this transition have been very uneven across States, consumption, poverty and social groups. The paper focuses on the drivers of this transition from the perspective of child poverty and its change at the household and state levels.

The paper is divided into eight sections. Section II deals with child population, trends, projections, changing total fertility rates, gender bias and child poverty. In section III we present estimates of child poverty and gender bias at the household level in 1993-94 and 2004-05 and comment on the change over time. Section IV is devoted to an analysis of children's education, child labor and children who are 'nowhere' ${ }^{1}$ among poor and non-poor households across states of India. In section $\mathrm{V}$ we present an analysis of change across various states in education, child labour and nowhere children between 1993-94 and 2004-05. Section VI focuses on demographic transition and its drivers using household data for 199394 and 2004-05. In particular, we focus on the role of girls schooling and poverty reduction using Probit and Logit analysis. Further, schooling and poverty reduction are analyzed using simultaneous equations system. Section VII highlights the need for gender and poverty sensitive inclusive, quality National education to ensure actualization of potential demographic dividend as envisioned by Right to Education Law of 2010. Conclusion and policy implications are presented in the section VIII.

\section{Child Population, Poverty and Demographic Transition}

Child population (under 15 Years) of India peaked at 365 million in 2001. Trends in child population from 1951 to 2001 and projections to 2026, including its subgroups by gender are presented in figure 1. In1951 girls constituted 48.7 percent of 134 million children,

\footnotetext{
1 'Nowhere' children are those who are neither in school nor engaged in child labour.
} 
suggesting 1.7 million missing girls due to gender bias. The number of missing girls rose to 7.7 million in 2001 suggesting worsening of gender bias in absolute and percentage terms in 50 years. In the absence of effective policy interventions, it is expected to get worse as can be seen in figure 1 for projections to 2026. However, the overall size of child population will continue to decline with rise in some states and decline in others. ${ }^{2}$

\section{Figure 1 here.}

We present data on Total Fertility Rates (TFR) for India and its major States in figure 2. Differences in the levels and change in TFR across States during 1961-2001 have been large. In 1960 Haryana, Bihar and Jharkhand had TFR over 8, while Kerala, Andhra Pradesh, Orissa and Tamil Nadu had TFR of less than 6. Over the 50 years TFR declined in all states. Kerala, Tamil Nadu, Himachal Pradesh, Karnataka and West Bengal’s TFR is nearing 2 while that of Bihar, Rajasthan and Uttar Pradesh continues to remain high at around 4 with an All India average of 2.9. In 2011 it has declined to 2.6 while the State differences persist. Decline of TFR between 1991 and 2001 in all states has been impressive. Murthi et.al.(1995) attempt an explanation of the drivers using cross-section data from the pre-reforms period.

\section{Figure 2 here.}

Drawing on National Sample Survey (NSS) data the number of children growing up in absolute poverty in 1993-94 and 2004-05 in major states of India, by age-group, is presented in Figure 3. Seven states of India have a very large share of children living in poverty. Data for Figure 3 are in Appendix Table A1. Three large states, namely, Uttar Pradesh, Bihar and Madhya Pradesh have largest concentration of child poverty. Implications for poverty and education policies are enormous. The drop in child poverty between 1993-94 and 2004-05 is impressive. It declined in most states but increased in a few, viz., Rajasthan, Madhya Pradesh and Kerala. This should be a cause for serious concern. Both concentration and rise in the incidence of child poverty have implications for state level and national public policies. We examine the incidence of child poverty at the household level in the next section.

\section{Figure 3 here.}

\footnotetext{
${ }^{2}$ See Chaudhri and Jha (2011a) and Census of India 2011, Paper 1 on Population and Growth.
} 


\section{Child Poverty, Gender Bias Levels and Change 1993-94 and 2004-05}

We divide two large, representative, cross-section datasets (118527 and 108538 households in each) for 1993-94 and 2004-05 respectively into four subgroups according to per capita monthly expenditure (PCME). ${ }^{3}$ Households with PCME less than half the absolute poverty line are classified as very poor, those with PCME below the poverty line but more than half of it are considered moderately poor. Those with PCME above the poverty line but less than double of it are considered non poor low consumption group and household with PCME level more than double the poverty line are considered non poor high consumption group. The results are reported in Figure 4. Statistical differences in the means of each of these subgroups within a cross-section and pairwise comparisons between two cross- sections are significant at $1 \%$. A number of interesting contrasts appear to be relevant for our econometric analysis presented in section VI. The gender bias measured as number of girls per thousand boys is highest among the non-poor high consumption group and is lowest among the moderately poor groups in both the cross-sections, 11 years apart.

\section{Figure 4 here.}

The number of children per household is lowest, at less than one, in the non-poor high consumption group and highest, at 2.59, among moderately poor households. Between 199394 and 2004-05 the number of children declined in each of the sub-groups except among the moderately poor where it increased marginally to 2.59 from 2.38. Children to adults ratio, a proxy for dependency rates, was highest among the poor and lowest among the non-poor households, following a monotonic decline in both the cross-sections. Over these eleven years female participation in the labour force increased among the non-poor and moderately poor, but declined among the very poor households. The share of children among the poor is substantially higher than their share in total population. Two drivers, probably re-enforcing inter-generationally as well, resulting in these outcomes are slower demographic transition among the poor and much higher dependency ratios in these households.

\footnotetext{
${ }^{3}$ Our chosen Poverty Line is the lowest one, devised and used in India since 1962, usually referred to as the ‘Absolute Poverty Line'. The Planning Commission (2009) and UNDP (2010) add more dimensions of poverty, raising the proportion of poor much higher.
} 


\section{Education, Child Labor and Nowhere Children (2004-05)}

In this section we discuss participation in school education, child labour and being Nowhere at the state level. The household data, presented in four subgroups in the preceding section, is merged into two, namely, children growing up in poor households and those growing up in non-poor households. The household data, grouped by states, for school education and exclusion from schools is reported in figure 5. The figure has two segments, one (5P) dealing with children growing up in households below the poverty line and the second (5NP) representing children growing up in households above the poverty line.

\section{Figure 5 here.}

A number of interesting patterns are noticeable. First, proportion of children attending schools among the non-poor is higher than the proportion among the poor in all States of India. Second, states like Uttar Pradesh, Bihar and Madhya Pradesh have a very large share of total child population of India (Chaudhri and Jha 2011a). The Planning Commission of India, has characterized these (and 5 other states) as Empowered Action Group (EAG) states, implying that these need to be the focus of assistance for bringing them at par with the rest of India. In the EAG states the gap between children attending schools among the poor and the non-poor is much larger than in the rest of India. For example, in Uttar Pradesh, 81.9\% of the non-poor children were attending schools while only 69.4\% children from among the poor were attending schools. In contrast, in Himachal Pradesh 96.3\% of the non-poor and $85.7 \%$ of the poor children were attending schools. As could be expected, the residual category of child labour and Nowhere children (The Planning Commission calls OoSC) in the EAG states is substantially higher than that of the all India average or non EAG states. In the Nowhere category, there is preponderance of girls (Chaudhri and Jha 2011d). A number of states have over $90 \%$ children in schools irrespective of poverty status suggesting that education policies play a crucial role in elementary education strategies. Naturally these states have a very small proportion of children reported as child labourers. We comment on the new Right to Education Law (2010) in section VII.

\section{Education and Exclusion: Change Across States (1993-94 to 2004-05)}

In Figure 6 we present data, depicting change between 1993-94 and 2004-05 and exclusion in major states of India. In this figure, distinction between children growing up in poverty and the non-poor is subsumed. As can be seen from the figure, change in positive direction is 
substantial and impressive. All of it cannot be attributed to prosperity. A major public effort to bring excluded children to schools under its Sarva Shiksha Abhiyan (Education for All, henceforth SSA), with greater emphasis since 2002, has had an important effect. ${ }^{4}$ Chaudhri and Jha (2011a) provide details and section VII in this paper contains a summary.

\section{Figure 6 here.}

The incidence of child labour registered an impressive decline in Andhra Pradesh, Tamil Nadu, Karnataka and Rajasthan. Although it declined in all other states, it increased in Kerala, Delhi and Jammu and Kashmir. Decline in the number of Nowhere children (girls have a large share in this group) was impressive in Uttar Pradesh, Andhra Pradesh, West Bengal and Madhya Pradesh. The number in this group declined in all states of India except Bihar where it increased marginally. This can be seen in figure 6 .

Participation in schools has increased substantially in large EAG states, in particular, Uttar Pradesh, Bihar, Madhya Pradesh and Rajasthan. Among the non-EAG states, Andhra Pradesh, West Bengal and Maharashtra also had impressive improvements in school enrolments.

The analysis presented so far is based on nationally representative household data. On school enrolments, this provides a picture of the demand side of schooling. Educational statistics based on school records and aggregated to state and national levels represent the supply side of school education. Ex post, normally, the two should match. These do tally for Kerala, Tamil Nadu, Himachal Pradesh and a few other states. The discrepancy observed in EAG states ranges between 12 and 20\% with school enrolment statistics presenting a rosier picture. For earlier decades, AERC (1971), Chaudhri (1996), Sen (1971) had highlighted this discrepancy and attributed it to dropouts from schools, mainly due to poverty and opportunity cost reasons. ${ }^{5}$ The dropouts from schools usually occur near the harvest and sowing seasons in rural areas and comparable employment needs pressures during festive seasons in the urban areas. Data presented above does not include the dropouts from schools and also does not give us any information about the quality of educational experience and its outcomes. We discuss parts of these in section VII.

\footnotetext{
${ }^{4}$ See Govinda (2008) and also Ministry of Human Resources website for details.

${ }^{5}$ Chaudhri \& Jha (2011b) provide a similar explanation for discrepancy in 2009-10 data.
} 


\section{Results of Estimation- Demographic Transition and the Causal Chain}

In Table 1 we present results on an OLS estimation (with Robust Standard Errors) for the number of children (aged 0-14) at the household level in the NSS rounds in 1993-94 and 2004-05. ${ }^{6}$ As expected the number of children rises with the number of females in the childbearing ages with the maximal impact of females aged 26-35 years. The higher the number of girls aged 5-14 not in school the greater the number of children. As expected, the higher the average level of education of females ${ }^{7}$ in the household the lower the number of children and the number of children declines with of monthly per capita expenditure (MPCE). However, this effect is non-linear since a quadratic term in MPCE is positive and significant in both samples. The higher the health share of total expenditure the larger the number of children. SC households have fewer children than 'other' households whereas ST households had fewer children in 1993-94 but these effects were insignificant in 2004-05. Muslim households have more children than households in the 'other' category. A dummy for the relatively less well-off states of Bihar, MP, UP, Orissa and Rajasthan is positive and significant in both time periods. Ceteris paribus, rural households have fewer children than urban households. ${ }^{8}$ Table 1 also shows the differences in coefficients and the significance of these differences.

\section{Table 1 here.}

These results were confirmed using Probit estimation, results of which are reported in Table 2. The dependent variable is whether a household has at least one child in the age group 0 to 14 years. As expected the greater the number of females in the childbearing age groups the greater the possibility of the household having at least one child in the age group $0-14$. This impact is highest for the age group 26-35 years. As in the case of the OLS estimation the higher the average education of females in the households the lower is the probability of there being a child in the age group 0-14. As expected, the higher the average level of education of females in the household the lower the number of children and the number of children declines with of monthly per capita expenditure (MPCE). However, this effect is non-linear since a quadratic term in MPCE is positive and significant in both samples. SC and ST

\footnotetext{
${ }^{6}$ The differences between the means of all the relevant variables are statistically significant at $1 \%$. Therefore the two samples are not merged and analysed separately.

${ }^{7}$ The average level of education of females in the household is defined as (total number of years of education of females in the household)/number of females in the household.

${ }^{8}$ This may be of surprise to some. However, Census definition of 'urban' is based on number of persons living in an area. A number of large villages, due to population growth between 1991 \& 2001 were reclassified as Towns. Kundu (2011) provides details.
} 
households had smaller likelihoods of having a child than 'other' households in 1993-94. In 2004-05 the dummy for SC households was insignificant in whereas that for ST households changed sign and was significant. Muslim households have a higher probability of having at least one child than households in the 'other' category. The higher the share of health expenditures the greater is the probability that the household has a child in the age group 014. A dummy for the relatively less well-off sates of Bihar, MP, UP, Orissa and Rajasthan is positive and significant in both time periods. Ceteris paribus, rural households have a lower probability of having a child as compared to urban households. Table 2 also shows the differences in coefficients and the significance of these differences.

Table 2 here.

We modelled the probability of a household having one, two, three or more than three children using a multinomial logit model for 1993-94 and 2004-05 NSS sample data, with the base case being having no child. This helps us to understand how sensitive the number of children is to key independent variables. These results are reported in Table 3.

Table 3 here.

The higher the number of females aged 15-25 in the household the greater is the probability of having one child or four children and the lower is the probability of having two or three children. The higher the number of females in the age group 26-35 the lower the probability of having one child. The higher the number of women in this age group the lower was the probability of having two children in 1993-94 but this marginal effect was positive and significant in 2004-05, indicating that over time there is greater tendency to have two children for women in this age group. However, the greater the number of women in the age group 26-35 the greater the probability of having three or more than three children. Further and again as expected, the greater the number of females aged 36-49 in the household the lower the probability of having one or two children and the greater the probability of having three or more children in the household. In both time periods the number of girls aged 5-14 not in school did not have a significant effect on the probability of having one child in the household. In both time periods the higher the number of girls aged 5-14 not in school the greater the probabilities of having two and more children. The higher the level of education of females in the household the greater are the probabilities of having one and two children and the lower the probabilities of having three and more children. The higher the monthly 
MPCE the greater are the probabilities of having one child or two children but negative signs on the square terms indicate that these effects fall off with higher MPCE. The higher the MPCE is lower are the probabilities of having 3 or more children but these effects also fall with increasing MPCE. Health share of total expenditure typically has significant but very small effects on the probabilities of having one, two, three or more than three children. The probability that SC households have one child is insignificantly different from households of the 'others' category. The SC dummy is significant and negative in both years for the estimation for two children and for three and more children in 1993-94. For 2004-05 this dummy is insignificant for households having three or more children. The ST dummy is significant and negative for the one child case in 2004-05 for one child, for the three children case in 1993-94 and the more than three children case in 1993-94. This dummy is positive and significant for three and more than three children in 2004-05. In all other cases it is insignificant. In both years Muslim households have lower probabilities of having one child or two children and higher probabilities of having three or more than three children. The dummy for the states of Bihar, MP, UP, Orissa and Rajasthan is negative and significant for the one child and two children cases in both years whereas it is positive and significant for three and more than three children. Households in rural areas have higher probabilities of having one or two children (except for the two child case in 2004-05 where this dummy is negative and significant) and lower probabilities of having three or more children.

\section{Table 4 here.}

In Table 4 we report on differences in odds ratios of differences across households in the probability of having different number of children. Thus, in 2004-05, poor households had 18.53 \% lower odds (as compared to very poor households) of having one child as opposed to no children. These computations reveal that households with lower MPCE had higher odds of having one or more children (as compared to no children) than households with higher MPCE. This was true for both sample periods. In both sample periods households from backward castes had higher odds of having one or more children (as compared to no children) than households from non-backward caste background. ST households had higher odds of having one or more children in 2004-05 but lower odds in 1993-94. SC households had lower odds of having one or more children (as compared to no children) in both time periods. 
In both time periods Muslims had higher odds of having one or children (as opposed to no children) than non Muslim households. The dependency of this odd ratio on the average education of females in the households is also depicted in Table 4. In 2004-05 households with higher levels of average female education had higher odds of having one child as compare to no children. But for all other pair-wise comparisons for 2004-05 and for all pairwise comparisons in 1993-94 higher levels of average education of females were associated with lower odds of having one or more children as opposed to no children.

In Table 5 we report on an Instrumental Variable estimation for the number of children (5-14 years) in school. In the first stage the number of children (0-14) in a household is estimated using household level data for 1993-94 and 2004-05 and then the predicted value of the number of children is used as an instrument to model the number of children in school. For both years in the first stage regression (for the number of children) the numbers of females in child bearing age groups are significant. The coefficient is highest for females aged 26-35. The number of girls not in school and education of head positively influence the number of children. As expected, the average education level of females in the household has a negative impact. The higher the MPCE the lower is the number of children. But this effect falls with increases in MPCE. The greater the health share of total expenditure the greater the number of children. In 1993-94 SC and ST households tended to have larger number of children but their effect was positive and significant in 2004-05. The Muslim dummy is positive and strongly significant in both years. In both years rural households tended to have fewer children.

\section{Table 5 here.}

In the IV estimation of the number of children in school the instrumented number of children estimated from the first equation is positive and is strongly significant in both years. The higher the dependency ratio the greater is the number of children in school. The bias against sending girls to school gets reflected in the sign (negative) and strong significance of the variable 'number of girls not in school.' The higher the education level of the head the larger the number of children sent to school in 1993-94 but this effect was negative and significant in 2004-05. As expected higher average education of females the greater is the number of children in school. As expected the higher the MPCE the greater is the number of children sent to school but this effect falls off with higher MPCE. The higher the share of health in total expenditure the lower is the number of children sent to school. Ceteris paribus SC, ST 
and Muslim households sent fewer children to school. Rural households were more likely to send children to school whereas households in the states of Bihar, MP, UP, Orissa and Rajasthan sent fewer children to school.

\section{Right to Education, Gender and Poverty Sensitive Law}

Beginning April, 2010, the Indian State is legally obliged to provide elementary school education to all children (6-14 years) in India. The constitution of India provides four levels of guarantees and protections for the children. The preamble expressly excludes all forms of discrimination. Article 21 broadly specifies the fundamental rights. Article 45 exhorts the state to provide free and compulsory education to all children up to the age of 14 within 10 years from the establishment of the Republic in 1950. Articles 26 and 32 prohibit employment of children in specified hazardous activities. And yet, virtually half of India's children were denied this right till 1991, with children from households in poverty having a dominant share among those excluded. To remedy this, the constitution was amended in 2002 and enabling legislation, the Compulsory and Free Education Act 2009 was passed. Mahatma Gandhi, commenting on a law on untouchability had stated, 'There is no right, but legal'.9 The new law provides fifth, but enforceable child's right to education. This, we believe, is a game changer provided it is implemented in letter and spirit.

The Education Commission Report (GOI 1966) titled, Education and National Development, was the Republic's first comprehensive study of the links between National Development and the foundational role of Education. Naik, who had been member secretary of the commission (1964-66), summarizes the role of education as stated in the report,

'The new education, in the commission's view, should be based on a deep and widespread study of science and technology; should cultivate a capacity and willingness to work hard and be closely related to productivity; should strengthen social and national integration and help to create a more just and egalitarian social order; should consolidate democracy as a form of government and help us to adopt it as a way of life; and should help us to strive to build social, moral and spiritual values'.10

'Education is a double-edged sword; while wrong education could lead to social disintegration, the right kind of education can bring about effective national development. The most effective way of breaking the vicious circle in which we find ourselves at present is to begin an educational reconstruction in a big way. That is why the commission placed

\footnotetext{
${ }^{9}$ See Dasgupta (1996), p.52 quoting original in Harijan, 17 April, 1937, in Complete Works 65, p.48.

${ }^{10}$ See Naik (1980), pp. 61-4.
} 
the highest emphasis on creation of a national system of education through an educational revolution... If we desire to get out of this vicious circle, create an egalitarian society and an egalitarian education system, we must mount a big offensive on both social and educational fronts. ${ }^{, 11}$

The commission had correctly identified the elitist character of Indian society.

The RTE law promises to remedy this. However, implementing a national system of education, with a degree of egalitarianism, would be a challenge. The Jamait Ulama-e-Hind is already quoting Article 30 of the Constitution on minorities educational rights and is threatening to challenge it. Others, when asked to accept 25\% of students from the deprived sections are not likely to be far behind. ${ }^{12}$ These need to be dealt with resolutely but with social sensitivity. Egalitarian society without a level playing field in education would be an illusion. Risks of a dualistic model of education persisting, partly due to elitism but mainly due to the additional cost of providing quality education with a uniform national minimum standard, are serious. Thus cheating the poor with poor quality education may continue. There shall be no legal remedy or protection against such eventualities.

Probe Report II (2011) has given us timely reminders that rising enrolments in schools does not imply actual education and learning. Emerging evidence should ring alarm bells among the educationists. Based on field surveys, the team reports we have:

'In rural North India, about half of the time, there was no teaching going on in primary schools in 1996-97. Ten years later (2006) nothing had changed in this respect...School participation has improved dramatically...This surge in school participation reflects a range of positive initiatives during the past 10 years. ${ }^{13}$

The Annual Status of Education Report (ASER) prepared by an NGO, PRATHAM, reports that almost half the children in class 5 cannot read a class 2 text or do sums in mathematics. ${ }^{14}$ The issue of neglect of elementary education has been extensively commented upon. However, the urgency of having to deal with it is keenly felt since RTE law became operational. $^{15}$

\footnotetext{
${ }^{11}$ See Naik (1980), ibid p.67

${ }^{12}$ Public interest litigation (PIL) that led to positive supreme court judgments on education as a right in 1993 and 1996 can help keep the issue in focus. See Aparna Bhatt (2005).

${ }^{13}$ PROBE II led by A. Shiva Kumar et.al

${ }^{14}$ See ASER (2011).

${ }^{15}$ See Naik (1975, 1980), Weiner (1991), Dreze \& Sen (1992, 1995), Chaudhri (1996, 2010) among many others.
} 
Chaudhri \& Jha (2011e) , commenting on The Planning Commission’s Approach paper on The $12^{\text {th }}$ FYP, point out, 'Analytically, 8 years of quality school education meeting national standards envisioned by RTE in India has three distinct segments, with minimum overlap. These are:

(a) Best quality education that money can buy with direct and indirect government support. Upper income class Indians keep this segment well managed and resourced and also insulated. The RTE requires that 25\% of their enrolment come from excluded children from their neighbourhoods. State needs to ensure that we keep potential 'Dronacharyas' from treating them as 'Eklavyas'!

(b) Quality education that follows the principles of demand and supply is delivered efficiently at reasonable cost with as much subsidy from the state has been growing as fast as our middle class and aspirational lower strata of society. The middle class, estimated at 350 million, with less than one child in each family, has been demanding and getting such education for the last many decades. The 25\% rule under RTE applies to this large and growing segment as well.

(c) Beneficiaries of Sarva Shiksha Abhiyan (SSA) effort since 2002 are the residual category consisting of approximately half of India’s 365 million (under 15) children as per census 2001. That a large part of this group of children is growing up in households living in absolute poverty, needs to be the focus in the $12^{\text {th }}$ FYP. Child poverty reduction and RTE are organically intertwined. Treating them as separate issues of poverty and RTE, we believe, would be a serious mistake.’

The RTE law is a potential game changer. It provides the policy makers an opportunity to ensure that expected demographic dividend is available to all youth of India in the $12^{\text {th }}$ FYP (April 2012-March 2017). Resource and management issues need not become binding constraints.

\section{Conclusions}

This paper has highlighted some key characteristics of the demographic transition and child education and their relation to household poverty status in India. Total fertility rates have declined for the country as a whole and for all states over the last three censuses of India. However, declines in some states e.g., Himachal Pradesh and some of the Southern States have been substantially in excess of the national average. Using household data from the NSS for 1993-94 and 2004-05 we show that households that are moderately poor have the largest number of children whereas the households with MPCE in excess of twice the poverty line have the smallest number of children. Thus the number of children in a household and MPCE have an inverter-U type relation. 
The dependency rate was highest among the poor and lowest among the non-poor households, following a monotonic decline in both the cross-sections. The share of children among the poor is substantially higher than their share in total population, i.e., child poverty is higher than poverty in the general population. Two drivers, probably re-enforcing intergenerationally as well, resulting in these outcomes are slower demographic transition among the poor and much higher dependency ratios in these households.

Further, the poor have a larger proportion of children out of school, particularly in the EAG states. There are wide variations across states and across rural and urban areas in the number of children in school, working as child labour and 'nowhere'. The paper also examines the determinants of the number of children in a household. The key determinants are (i) the number and age distribution of women in the child-bearing age groups (ii) average education of these women; and (iii) PCME of the household. Dummies for EAG states are significant as are dummies for social status, particularly Muslims.

We then modeled the decision to send children to school. We find that (i) the higher the average education of females the greater is the number of children in school; (ii) the higher the MPCE the greater is the number of children sen to school but this effect falls off with higher MPCE; and (iii) the higher the share of health in total expenditure the lower is the number of children sent to school. Further, the larger the number of girls in the household the lower the number of children sent to school, exhibiting a gender bias in education. Ceteris paribus SC, ST and Muslim households sent fewer children to school. Rural households were more likely to send children to school whereas households in the EAG states sent fewer children to school. Thus, for accelerating demographic transition in EAG states and among the households in absolute poverty, education, particularly of the girls is the key driver.

Finally, the paper argues that Indian children are faced with a three-tier education system. The rich are able to get the best quality education whereas middle class children are able to acquire quality education with considerable subsidy from the state. Children from relatively poor families, for whom the SSA is most relevant, typically get poor quality education and exhibit poor educational outcomes. The RTE implementation must explicitly recognize this incipient three-tier education system and pay attention to the quality of education for the poorest if India is to realize its demographic dividend. Potential benefits of equity and inclusive growth as well as population growth stabilization are enormous. 


\section{References}

AERC (1971), Primary Education in Rural India; Participation and Wastage, Agricultural Economics Research Centre, University of Delhi, Mumbai-New Delhi: Tata McGraw Publishing, 1971.

ASER (2011), Annual Status of Education Report (Rural) 2010, Mumbai: Pratham Resource Centre, Jan.

Bhatt, A. (2005), Supreme Court on Children, Delhi: Human Rights Law Network.

Chaudhri, D.P. (1996), A Dynamic Profile of Child Labour in India New Delhi: International Labour Office.

Chaudhri, D.P. (2010), ‘Child's rights and elementary education in India’, Prabuddha Bharata, December, 66975.

Chaudhri, D.P. and R. Jha (2011a), 'Child Poverty and Compulsory Education in India: Policy Insights from Household Data Analysis’, ASARC Working Paper 2011/04.

Chaudhri, D.P. and R. Jha (2011b), 'Child Poverty and Education', Economic Times, New Delhi, March.

Chaudhri, D.P. and R. Jha (2011c), ‘Money Does Buy Child’s Gender’, Economic Times, New Delhi, June.

Chaudhri, D.P. and R. Jha (2011d), 'India’s Gender Bias in Child Population, Female Education and Growing Prosperity: 1951-2011 with Projections to 2026’, ASARC Working Paper 2011/14.

Chaudhri, D.P. and R. Jha (2011e), 'Right to Education, Child Poverty and The Twelfth Five year Plan', Economic Times, New Delhi, forthcoming.

Dasgupta, Ajit. K. (1996), Gandhi’s Economic Thought, Routledge, London.

Dreze J. \& Amartya Sen (1995), Economic Development and Social Opportunity, Delhi: Oxford University Press. Dreze J. \& Amartya Sen (1997), Indian Development, Delhi :Oxford University Press.

Govinda, R. (2008), Access to Elementary Education in India: Country Analytical Review, New Delhi: National University of Educational Planning and Administration.

Government of India (1966), Education and National Development: Report of the Education Commission, New Delhi: Ministry of Education, Government of India.

Government of India (2009), The Rights of Children to Free and Compulsory Education Act 2009, The Gazette of India, No 39, Ministry of Law and Justice, New Delhi.

Kundu, Amitabh (2011), 'Method in Madness: Urban Data from 2011 Census', Economic and Political Weekly, Vol. 46(40), 1 October.

MHRD (2009), Website: http://www.education.nic.in/ for details on the 2009 Act.

Murthi, Mamta, Anne-Catherine Guio, Jean Drèze (1995), 'Mortality, Fertility, and Gender Bias in India: A District-Level Analysis’, Population and Development Review, Vol. 21(4): pp. 745-82, Jan.

Naik, J.P. (1975), Elementary Education in India: A Promise to Keep, Delhi, Allied Publishers.

Naik, J.P. (1980), Reflections on the Future of Development of Education in India, Paris: UNESCO, pp. 61-4.

National Sample Survey (2011), Details of National Sample Survey data available at http://mospi.nic.in/nsso_4aug2008/web/nsso.htm

Planning Commission of India (2009), 'Expert Committee Report on Poverty Measurement', New Delhi: Planning Commission of India.

Planning Commission of India (2011), 'Faster, Sustainable and More Inclusive Growth: Approach to The 12th FYP, Draft Paper', New Delhi: Planning Commission of India, Aug.

Pratham (2011), Pratham is an NGO devoted to the cause of Elementary Education in India. Details are in: www.pratham.org.

PROBE II led by A. Shiva Kumar et al. (2010), Education for all is the policy, but what is the reality?, Chennai: Frontline, Vol. 26(6).

Registrar General of India (various years), Census of India, New Delhi: Registrar General’s Office.

Registrar General of India (2006), Expert Committee Report on Population Projections till 2026, New Delhi: Registrar General’s Office.

Sen, Amartya (1971), ‘Aspects of Indian Education’, Text of Lal Bahadur Shastri Memorial Lecture 1970, reprinted in C. Malik (ed.), Management and Organization of Indian Universities, Simla: Indian Institute of Advanced Study.

UNDP (2010), Human Development Report 2010, UNDP, New York.

Weiner, Myron (1991), The Child and The State in India, Princeton: Princeton University Press. 
Figure 1: Child population (0-14 years with sub-groups) of India by gender and age groups in 1951-2001 with projections to 2026

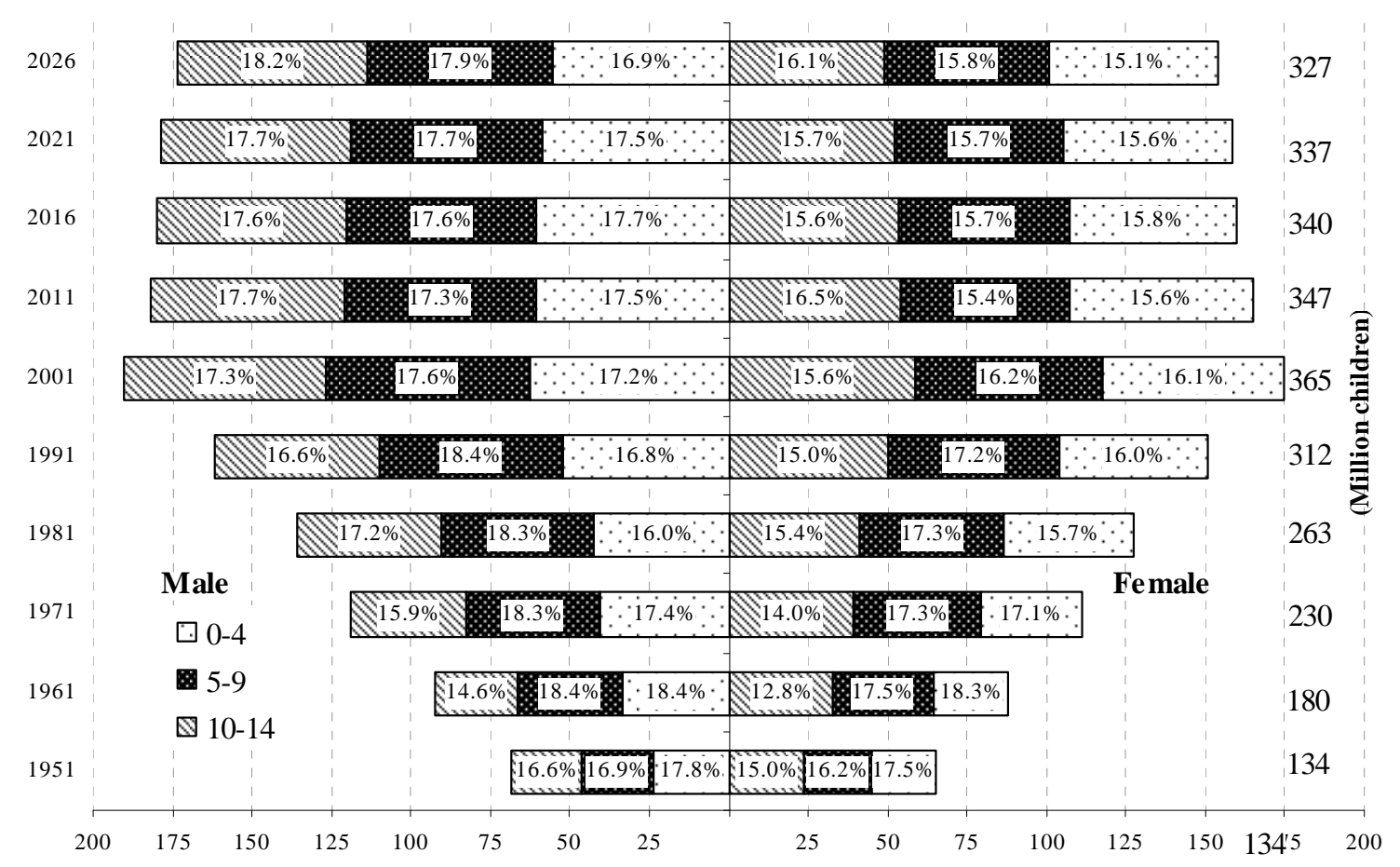

Sources: 1. Chaudhri, D.P. (1996), A Dynamic Profile of Child Labour in India 1951-91, CLASP, ILO New Delhi, June 1996

2. Census of India 2001, Population Tables and Population Projections for India and States 2001-2026 
Figure 2: Total fertility rates in major states of India 1961-2001

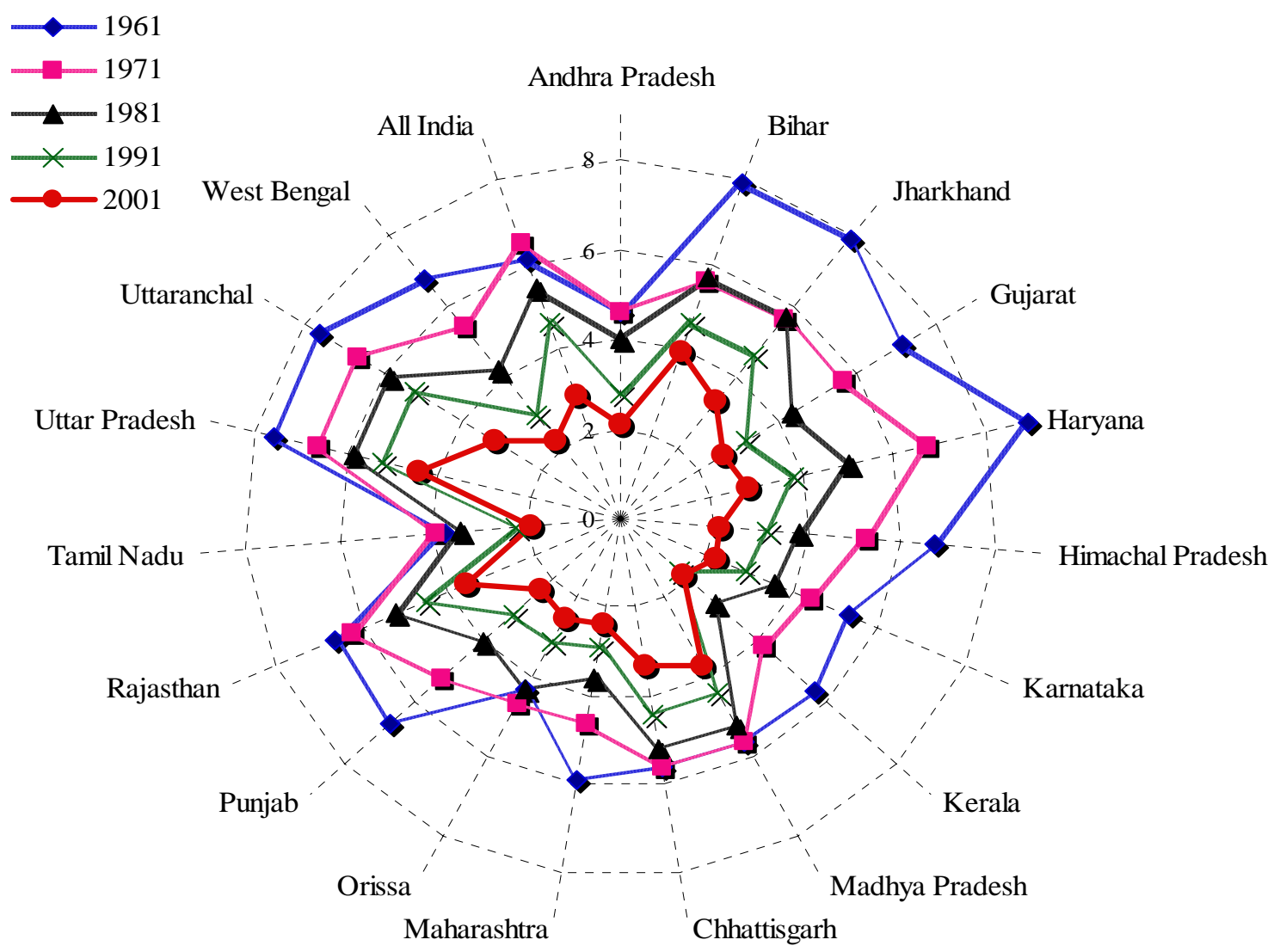

Sources: 1. Census of India 1961, 1971, 1981, 1991 and 2001

2. Ron C. Mittelhammer, Tauhidur Rahman (2004), Distribution of Human Development, Child Labor and Poverty in India.

3. National Commission on Population MHFW 2006

4. Chaudhri and Jha 2011d, 'Child Poverty and Elementary Education in India', ASARC Working Paper 2011/04. 
H'igure 3: Child poverty in 200+-05 and $1993-9+$ in major

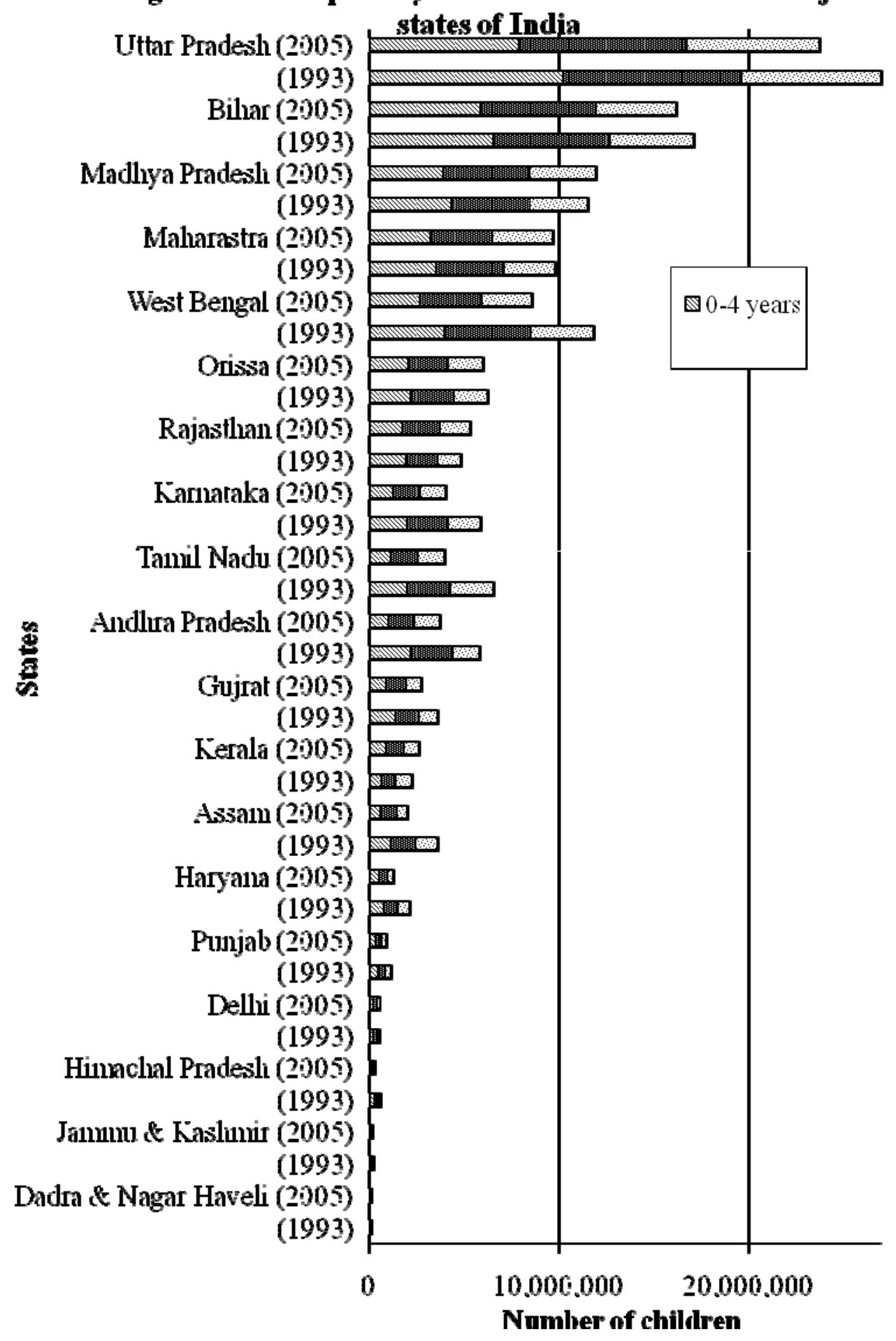


Figure 4: Household size, number of children (0-14) in poor and non poor households in India

2004-05

Very Poor
$(H H$ size* $=4.45)$
$(G B$ children $=938)$

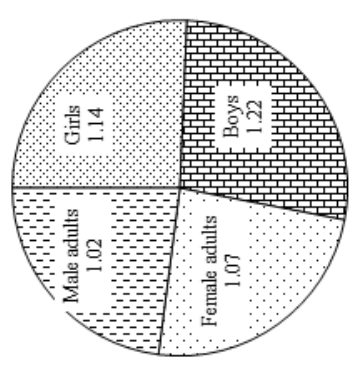

Very Poor

(HH size* $=5.62)$

(GB children $=982$ )

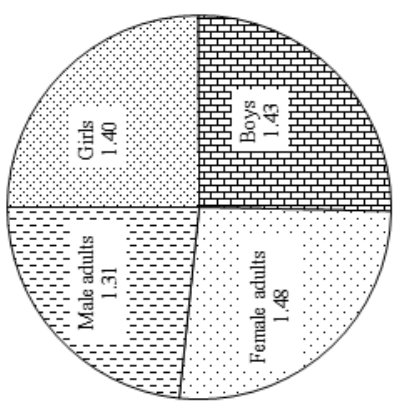

Moderately Poor

$($ HH size $*=5.87)$
$($ GB children $=981)$
Non-poor Low
$\left(H H\right.$ size $\left.{ }^{*}=4.84\right)$

$($ (GB children $=889$ )
Non-poor High

$($ HH size* $=3.59$ )

( $G B$ children $=824$ )
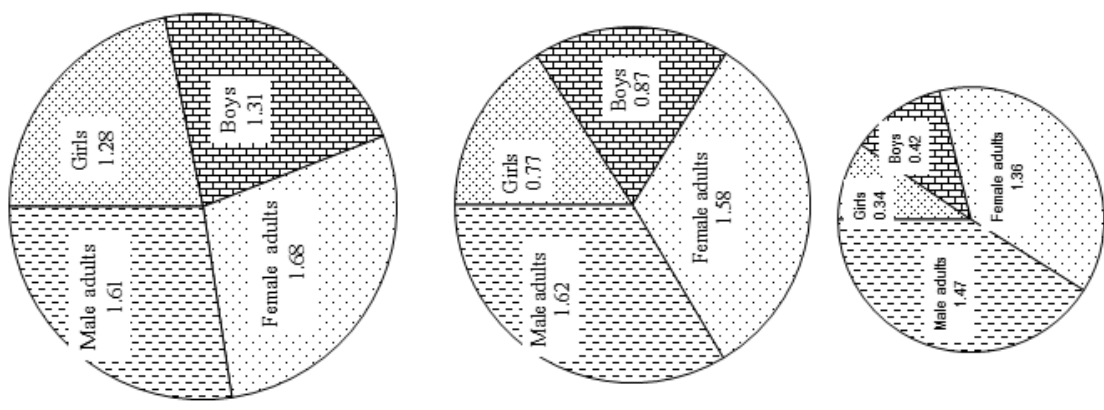

\section{3-94}
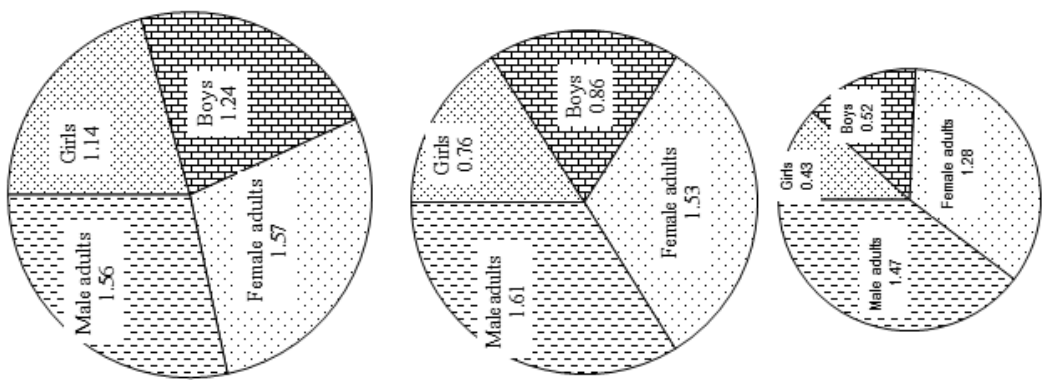

Sources: 1. Computed from NSS 61st Round for 2004-05 and NSS 50th Round for 1993-94

2. 'Poverty estimates for 2004-05', Press Information Bureau of Government of India, New Delhi, March-2007

3. Savita Sarma, 'Poverty Estimates in India: Some key issues', ERD Working Paper Series No. 51, ADB, May 2004.

4. Chaudhri and Jha 2011d, 'Child Poverty and Elementary Education in India', ASARC Working Paper 2011/04.

Notes: 1 . all pairwise comparisons of differences in mean values of household size are statistically significant at $1 \%$ within the two samples and also between 1993-94 and 2004-05

2. all pairwise comparisons of differences in mean values of number of girls, boys, female adults and male adults are statistically significant at $1 \%$ within the two samples and also between 1993-94 and 2004-05 
Figure 5P: Children in poverty (5-14 years) in schools, labour

force and non-participation in major states of India 2004-05

Number of children

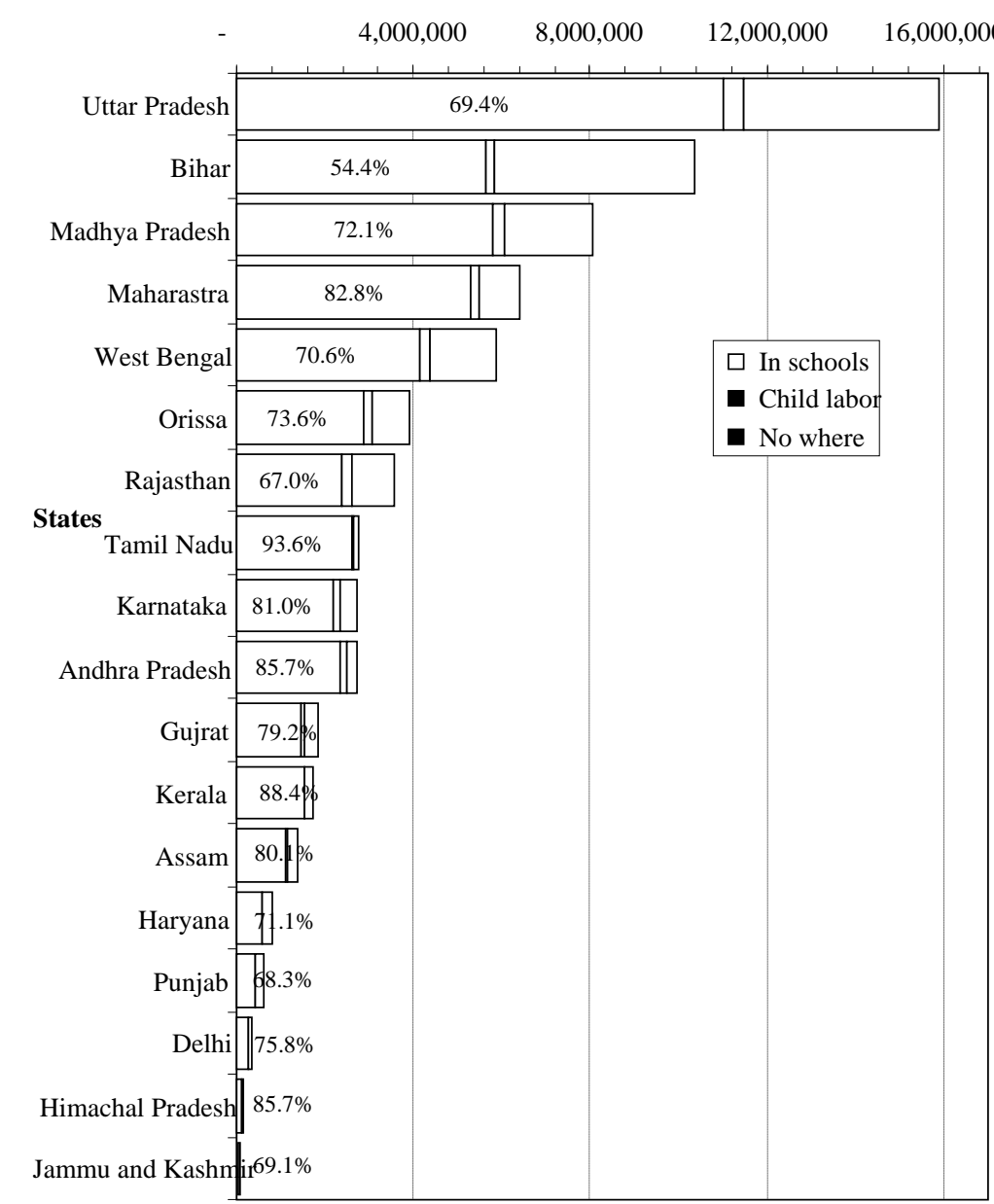

Figure 5NP: Non-poor children (5-14 years) in schools, labour force and non-participation in major states of India 2004-05

Number of children

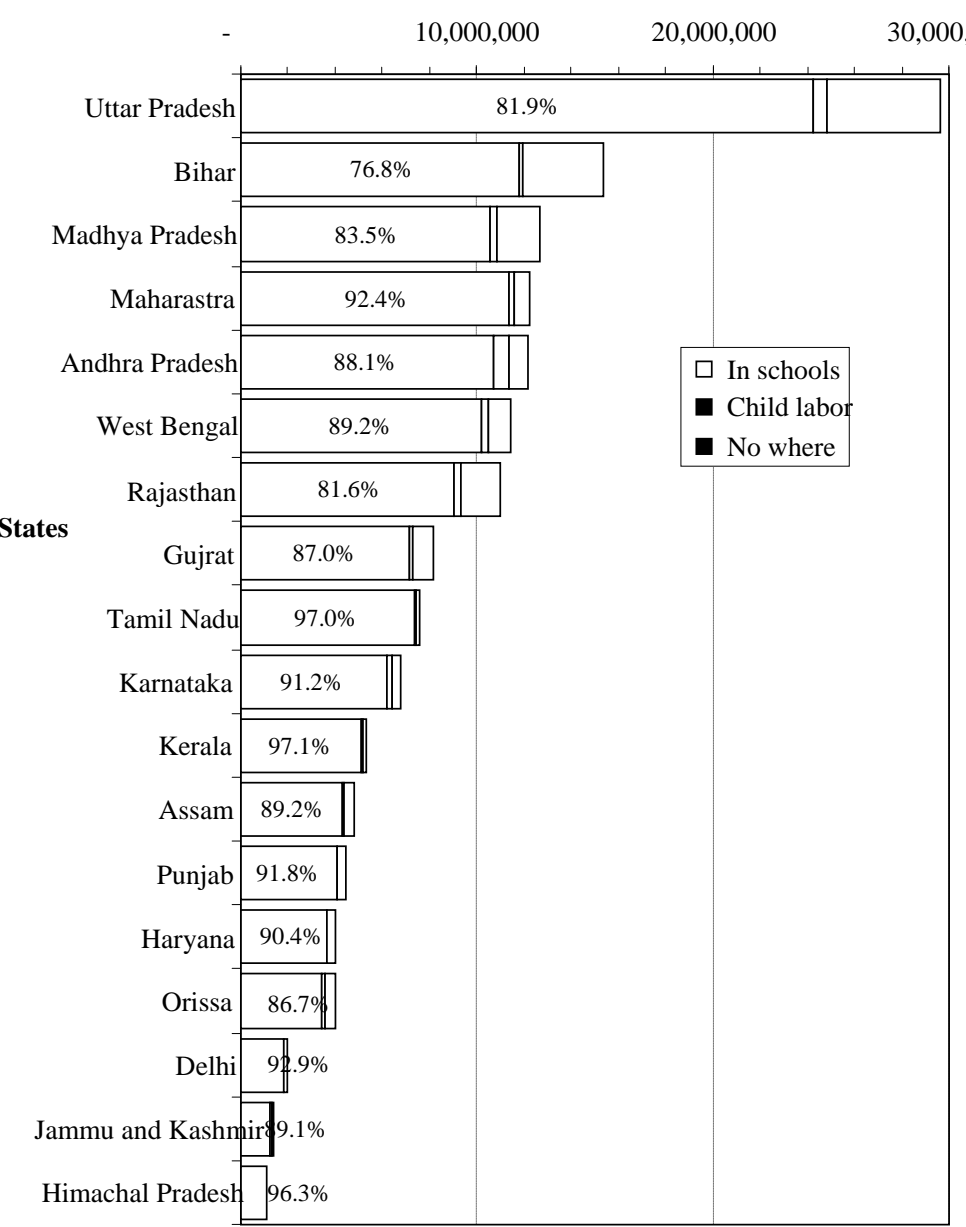

Sources: 1. Computed from NSS 61st Round for 2004-05 and NSS 50th Round for 1993-94

2. Chaudhri and Jha 2011d, 'Child Poverty and Eementary Education in India', ASARC Working Paper 2011/04. 
Figure 6: Change in children's participation in schooling, child labour and non-participation

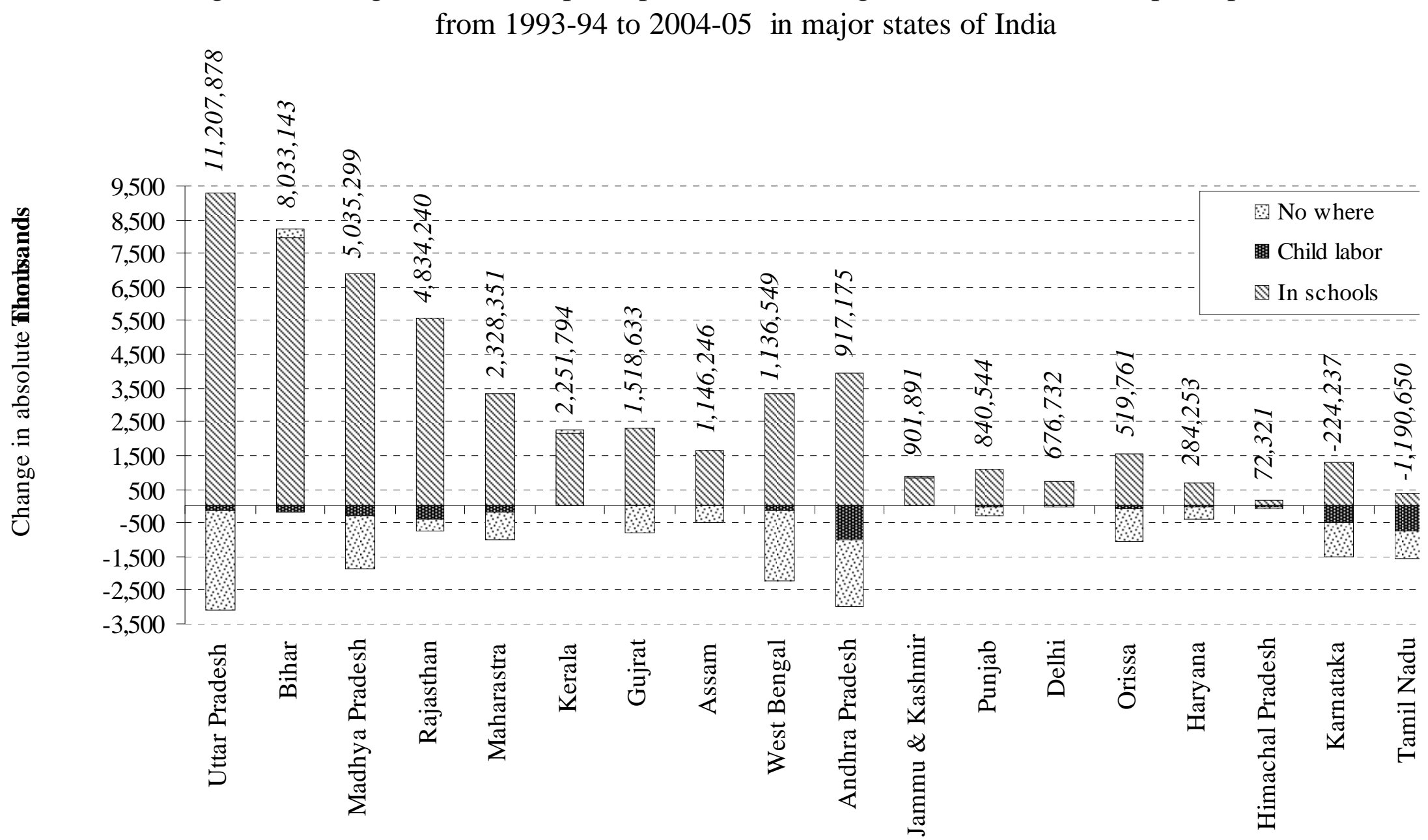

Sources: 1. Computed from NSS 61st Round for 2004-05 and NSS 50th Round for 1993-94

2. Chaudhri and Jha 2011d, 'Child Poverty and Elementary Education in India', ASARC Working Paper 2011/04. 
Table 1: OLS Model, Robust SE

(Dependent variable is number of children aged 0 to 14)

\begin{tabular}{|c|c|c|c|}
\hline Variables & 1993-94 & 2004-05 & $\begin{array}{c}\text { Difference between } \\
\text { 2005-1993 } \\
\end{array}$ \\
\hline No. of females aged 15-25 & $0.246^{\star \star *} \quad(0.00811)$ & $0.182^{* * *} \quad(0.00708)$ & $-0.064^{\star \star \star}$ \\
\hline No. of females aged 26-35 & $1.378^{* \star *} \quad(0.0131)$ & $1.318^{* * *}(0.0114)$ & $-0.060^{\star * *}$ \\
\hline No. of females aged 36-49 & $0.469^{* \star *} \quad(0.0122)$ & $0.424^{* * *} \quad(0.00957)$ & $-0.045^{\star \star *}$ \\
\hline No. of girls not in schools & $0.973^{\star \star *} \quad(0.00884)$ & $1.041^{\star \star *} \quad(0.0124)$ & $0.068^{\star \star \star}$ \\
\hline Average education level of females & $-0.0424^{\star \star \star}(0.00153)$ & $-0.0385^{\star \star \star}(0.00134)$ & $0.004^{*}$ \\
\hline Per capita expenditure (Rupee 00) & $-0.0897^{\star \star \star}(0.00256)$ & $-0.0634^{* * *}(0.00225)$ & $0.026^{* \star *}$ \\
\hline Per capita expenditure/100 & $0.113^{* * *} \quad(0.00765)$ & $0.0550^{* \star *}(0.00476)$ & $-0.058^{\star \star *}$ \\
\hline Health share of total expenditure & $0.00174^{\star \star \star}(0.000279)$ & $0.00440^{\star * \star}(0.000451)$ & $0.003^{\star \star \star}$ \\
\hline Scheduled Caste & $-0.0893^{* * k}(0.0112)$ & $0.00939(0.0103)$ & $0.098^{* * *}$ \\
\hline Scheduled Tribe & $-0.0578^{\star \star \star}(0.0137)$ & $0.0814^{\star \star \star}(0.0121)$ & $0.138^{\star \star \star}$ \\
\hline Muslim & $0.348^{* \star *} \quad(0.0149)$ & $0.380^{* * *} \quad(0.0131)$ & $0.032^{*}$ \\
\hline Bihar, MP, UP, Orissa and Rajasthan & $0.213^{* * *}(0.00873)$ & $0.354^{* * *}(0.00845)$ & $0.141^{\star \star *}$ \\
\hline Rural areas & $-0.0560^{\star * \star}(0.00896)$ & $-0.0517^{k \star *}(0.00816)$ & 0.005 \\
\hline Constant & $1.137^{\star * \star} \quad(0.0167)$ & $1.160^{* * *}(0.0185)$ & \\
\hline Observations & 108,538 & 118,527 & \\
\hline F-statistics & $3,766.8$ & $3,879.7$ & \\
\hline p_value & 0.000 & 0.000 & \\
\hline Adjusted $\mathrm{R}^{2}$ & 0.361 & 0.359 & \\
\hline
\end{tabular}

Notes: Standard errors in parentheses ${ }^{*} p \leq 0.10,{ }^{* *} p \leq 0.05,{ }^{* * *} p \leq 0.01$

Sources: 1 . Computed from NSS 61th, 2004-05

2. Chaudhri and Jha 2011d, Child Poverty and Elementary Education in India', ASARC Working Paper 2011/04. 
Table 2: Probit Model, Robust SE

(Dependent variable $=1$ if $\mathrm{HH}$ has at least one child aged 0 to 14)

\begin{tabular}{|c|c|c|c|}
\hline Variables & 1993-94 & 2004-05 & $\begin{array}{c}\text { Difference between } \\
\text { 2005-1993 }\end{array}$ \\
\hline No. of females aged 15-25 & $0.230^{* \star *}(0.00801)$ & $0.176^{* k x}(0.00732)$ & $-0.054^{\text {t*t+x}}$ \\
\hline No. of females aged 26-35 & $1.214^{* \star *}(0.0153)$ & $1.200^{* \star *}(0.0155)$ & -0.014 \\
\hline No. of females aged $36-49$ & $0.258^{* \star *}(0.0108)$ & $0.232^{\star * \star}(0.0102)$ & $-0.026^{*}$ \\
\hline Average education level of females & $-0.0164^{* * *}(0.00185)$ & $-0.00395^{* *}(0.00168)$ & $0.013^{* \star * \alpha}$ \\
\hline Per capita expenditure (Rupee 00) & $-0.0873^{* * *}(0.00277)$ & $-0.0644^{4+1+}(0.00196)$ & $0.023^{*+* x}$ \\
\hline Per capita expenditure/100 & $0.101^{* * *}(0.00743)$ & $0.0464^{\star * *}(0.00378)$ & $-0.055^{\text {tik }}$ \\
\hline Health share of total expenditure & $0.000831^{* \star *}(0.000338)$ & $0.00269^{\text {tw* }}(0.000549)$ & $0.002^{* * *}$ \\
\hline Scheduled caste & $-0.0549^{* * *}(0.0135)$ & $-0.0138(0.0119)$ & $0.041^{\star *}$ \\
\hline Scheduled tribe & $-0.0272^{*}(0.0158)$ & $0.0424^{\star k *}(0.0138)$ & $0.069^{* * *}$ \\
\hline Muslim & $0.145^{\star * \star}(0.0165)$ & $0.216^{\star \star \star x}(0.0144)$ & $0.071^{\star * *}$ \\
\hline Bihar, MP, UP, Orissa and Rajasthan & $0.0753^{* * *}(0.0100)$ & $0.154^{\star \star *}(0.00954)$ & $0.079^{* * *}$ \\
\hline Rural areas & $-0.0661^{\star * \star}(0.0104)$ & $-0.0940^{+*+1}(0.00972)$ & $-0.028^{* *}$ \\
\hline Observations & 93,985 & 109,797 & \\
\hline chi2 & $9,302.9$ & $11,734.9$ & \\
\hline p_value & 0.000 & 0.000 & \\
\hline Pseudo- $R^{2}$ & 0.140 & 0.165 & \\
\hline
\end{tabular}

Notes: Marginal effects; Standard errors in parentheses

${ }^{*} p \leq 0.10,{ }^{* *} p \leq 0.05,{ }^{* * *} p \leq 0.01$

Sources: 1. Computed from NSS 61th, 2004-05

2. Chaudhri and Jha 2011d, 'Child Poverty and Elementary Education in India', ASARC Working Paper 2011/04. 
Table 3: Multinomial Logit Model, Robust SE

(Dependent variable $=0$ if $H H$ has no child aged 0 to $14,=1$ if $H H$ has 1 child aged 0 to 14 , $=2$ if $\mathrm{HH}$ has 2 children aged 0 to $14,=3$ if $\mathrm{HH}$ has 3 children aged 0 to $14,=4$ if HH has more than 3 children aged 0 to 14)

\begin{tabular}{|c|c|c|c|c|c|}
\hline Variables & \multicolumn{2}{|c|}{ 1993-94 } & \multicolumn{2}{|c|}{$2004-05$} & $\begin{array}{c}\text { Difference between } \\
\text { 2005-1993 } \\
\end{array}$ \\
\hline \multicolumn{6}{|l|}{ Dependent variable $=1$ versus 0} \\
\hline No. of females aged 15-25 & $0.006^{* * *}$ & $(0.0150)$ & $0.026^{\star \star \star}$ & $(0.0134)$ & $0.020^{\text {*** }}$ \\
\hline No. of females aged 26-35 & $-0.256^{\star \star \star}$ & $(0.0293)$ & $-0.206^{\star \star \star}$ & $(0.0275)$ & $0.050^{* * *}$ \\
\hline No. of females aged 36-49 & $-0.063^{*+\alpha}$ & $(0.0209)$ & $-0.043^{\star \star \star}$ & (0.0192) & 0.020 \\
\hline No. of girls not in schools & -0.138 & (.) & 0.218 & (.) & 0.356 \\
\hline Average education level of females & 0.012 & $(0.00360)$ & $0.015^{\star \star \star}$ & $(0.00322)$ & $0.003^{*+k}$ \\
\hline Per capita expenditure (Rupee 00) & $0.031^{\star \star *}$ & (0.00513) & $0.021^{\star \star \star}$ & (0.00318) & $-0.010^{* k *}$ \\
\hline Per capita expenditure/100 & $-0.033^{\star \star \star}$ & $(0.0135)$ & $-0.013^{\star \star \star}$ & $(0.00561)$ & $0.020^{\star \star \star}$ \\
\hline Health share of total expenditure & -0.000 & $(0.000689)$ & $-0.001^{\star *}$ & $(0.00106)$ & -0.001 \\
\hline Scheduled caste & 0.034 & $(0.0272)$ & 0.010 & $(0.0244)^{\prime}$ & -0.024 \\
\hline Scheduled tribe & 0.016 & $(0.0315)$ & $-0.011^{\star \star \star}$ & (0.0271) & $-0.026^{*}$ \\
\hline Muslim & $-0.050^{* \text { **t }}$ & $(0.0340)$ & $-0.054^{* * *}$ & (0.0298) & $-0.004^{* *}$ \\
\hline Bihar, MP, UP, Orissa and Rajasthan & -0.031 & $(0.0203)$ & $-0.035^{\star \star \star}$ & $(0.0195)$ & $-0.004^{\star \star \star k}$ \\
\hline Rural areas & $0.026^{\star \star \star}$ & $(0.0208)$ & $0.013^{\star \star \star}$ & $(0.0193)$ & $-0.013^{\star \star \star}$ \\
\hline \multicolumn{6}{|l|}{ Dependent variable $=2$ versus 0} \\
\hline No. of females aged $15-25$ & $-0.010^{* * *}$ & $(0.0157)$ & $-0.012^{* k *}$ & $(0.0146)$ & $-0.002^{*+k}$ \\
\hline No. of females aged 26-35 & $-0.011^{\star \star \star}$ & $(0.0289)$ & $0.062^{\star \star \star}$ & $(0.0278)$ & 0.073 \\
\hline No. of females aged 36-49 & $-0.047^{\star \star \star}$ & $(0.0217)$ & $-0.047^{\star \star \star}$ & (0.0203) & $0.000^{\text {thk }}$ \\
\hline No. of girls not in schools & $0.047^{\star \star \star}$ & $(0.0277)$ & $0.416^{\star \star \star}$ & $(0.0369)$ & 0.369 \\
\hline Average education level of females & $0.004^{\star \star *}$ & $(0.00376)$ & $0.001^{\star \star \star}$ & (0.00338) & $-0.003^{\star k \star}$ \\
\hline Per capita expenditure (Rupee 00) & $0.011^{\star \star *}$ & $(0.00598)$ & $0.002^{\star \star \star}$ & $(0.00375)$ & $-0.009^{\star \star \star}$ \\
\hline Per capita expenditure/100 & $-0.009^{* k t}$ & $(0.0165)$ & $-0.000^{* \star *}$ & (0.00732) & $0.009^{*+k}$ \\
\hline Health share of total expenditure & $-0.000^{\star \star \star}$ & $(0.000686)$ & $-0.000^{\star \star \star}$ & $(0.00112)$ & $0.000^{* \star *+}$ \\
\hline Scheduled caste & $-0.011^{\star \star \star}$ & $(0.0274)$ & $-0.025^{\star \star}$ & $(0.0244)$ & -0.014 \\
\hline Scheduled tribe & 0.004 & $(0.0319)$ & -0.027 & $(0.0281)$ & $-0.031^{*}$ \\
\hline Muslim & $-0.044^{\star \star \star}$ & $(0.0337)$ & $-0.037^{\star \star \star}$ & $(0.0297)$ & $0.007^{\star \star \star}$ \\
\hline Bihar, MP, UP, Orissa and Rajasthan & $-0.025^{\star \star \star}$ & $(0.0204)$ & $-0.045^{\star \star \star}$ & (0.0196) & -0.02 \\
\hline Rural areas & $0.000^{* k *}$ & $(0.0210)$ & $-0.007^{\star \star \star *}$ & $(0.0196)$ & -0.007 \\
\hline \multicolumn{6}{|l|}{ Dependent variable $=3$ versus 0} \\
\hline No. of females aged $15-25$ & $-0.018^{* \star *}$ & $(0.0186)$ & $-0.012^{* \star *}$ & $(0.0182)$ & $0.006^{\text {tkt }}$ \\
\hline No. of females aged 26-35 & $0.124^{\star * \star}$ & $(0.0317)$ & $0.137^{\star \star \star}$ & $(0.0317)$ & $0.013^{*}$ \\
\hline No. of females aged 36-49 & $0.032^{* * *}$ & $(0.0254)$ & $0.046^{\star \star \star}$ & $(0.0252)$ & 0.014 \\
\hline No. of girls not in schools & $0.122^{* k *}$ & $(0.0271)$ & $0.278^{\star \star \star}$ & (0.0358) & $0.156^{* *}$ \\
\hline Average education level of females & $-0.008^{\star \star \star}$ & $(0.00464)$ & $-0.009^{* \star *}$ & $(0.00429)$ & $-0.001^{* *}$ \\
\hline Per capita expenditure (Rupee 00) & $-0.022^{\star \star \star}$ & $(0.00825)$ & $-0.016^{\star \star \star}$ & $(0.00544)$ & $0.006^{\text {tht }}$ \\
\hline Per capita expenditure/100 & $0.021^{\star \star \star}$ & $(0.0200)$ & $0.010^{\star \star \star}$ & $(0.0114)$ & $-0.011^{\star \star \star}$ \\
\hline Health share of total expenditure & $0.000^{* \star *}$ & $(0.000782)$ & $0.001^{\star \star \star}$ & $(0.00142)$ & $0.001^{\text {ktk }}$ \\
\hline Scheduled caste & $-0.013^{\star \star \star}$ & $(0.0306)$ & 0.010 & $(0.0285)$ & $0.023^{* \star * t}$ \\
\hline Scheduled tribe & $-0.013^{\star \star \star}$ & $(0.0366)$ & $0.031^{\star \star \star}$ & $(0.0335)$ & $0.044^{* k+}$ \\
\hline Muslim & $0.014^{\star \star \star}$ & $(0.0368)$ & $0.043^{\star \star \star}$ & (0.0337) & $0.029^{* k+k}$ \\
\hline Bihar, MP, UP, Orissa and Rajasthan & $0.013^{* k *}$ & $(0.0229)$ & $0.038^{* k *}$ & $(0.0226)$ & $0.025^{*+*}$ \\
\hline Rural areas & $-0.021^{\star \star \star *}$ & $(0.0244)$ & $-0.011^{\star \star \star}$ & $(0.0239)$ & 0.010 \\
\hline \multicolumn{6}{|l|}{ Dependent variable $=>3$ versus 0} \\
\hline No. of females aged $15-25$ & $0.024^{* * *}$ & $(0.0207)$ & $0.014^{\star \star \star}$ & $(0.0207)$ & $-0.010^{* * *}$ \\
\hline No. of females aged 26-35 & $0.160^{* * *}$ & $(0.0361)$ & $0.113^{\star \star \star}$ & (0.0368) & $-0.047^{\star k}$ \\
\hline No. of females aged $36-49$ & $0.082^{\star \star *}$ & $(0.0298)$ & $0.066^{\star \star \star}$ & $(0.0305)$ & $-0.016^{\star \star \star}$ \\
\hline No. of girls not in schools & $0.127^{\star \star \star}$ & $(0.0266)$ & $0.142^{\star \star \star}$ & $(0.0348)$ & 0.015 \\
\hline Average education level of females & $-0.009^{\star \star \star}$ & $(0.00580)$ & $-0.008^{\star \star \star}$ & $(0.00546)$ & $0.001^{*}$ \\
\hline Per capita expenditure (Rupee 00) & $-0.022^{\star \star \star}$ & $(0.0115)^{\prime}$ & $-0.014^{\star \star \star}$ & (0.00789) & $0.008^{* k+}$ \\
\hline Per capita expenditure/100 & $0.022^{\star \star \star}$ & $(0.0228)$ & $0.008^{\star \star \star}$ & $(0.0163)$ & $-0.014^{\star \star \star}$ \\
\hline Health share of total expenditure & $0.000^{\star \star \star}$ & $(0.000861)$ & $0.001^{\star \star \star}$ & $(0.00162)$ & $0.001^{\star \star \star}$ \\
\hline Scheduled caste & $-0.011^{* * \star}$ & $(0.0352)$ & 0.004 & $(0.0331)$ & $0.015^{*+*}$ \\
\hline Scheduled tribe & $-0.007^{\star \star \star}$ & $(0.0432)$ & $0.012^{* \star \star}$ & $(0.0409)$ & $0.019^{* k+k}$ \\
\hline Muslim & $0.081^{\star \star \star}$ & $(0.0387)$ & $0.063^{* \star \star}$ & $(0.0365)$ & $-0.018^{\star \star \star}$ \\
\hline Bihar, MP, UP, Orissa and Rajasthan & $0.044^{\star \star \star}$ & $(0.0258)$ & $0.053^{\text {*k* }}$ & $(0.0259)$ & $0.009^{\text {tak }}$ \\
\hline Rural areas & $-0.007^{\star k \star}$ & $(0.0289)$ & $-0.003^{* k *}$ & $(0.0287)$ & 0.004 \\
\hline Observations & \multicolumn{2}{|c|}{108,538} & \multicolumn{2}{|c|}{118,527} & \\
\hline Pseudo-R² & \multicolumn{2}{|c|}{0.143} & \multicolumn{2}{|c|}{0.152} & \\
\hline
\end{tabular}

Sources: Computed from NSS 61th, 2004-05; Chaudhri and Jha, 'Child Poverty and Elementary Education in India', ASARC WP 2011/04. 
Table 4: Percentage Change in Odd Ratios in India, 1993 and 2005

\begin{tabular}{|c|c|c|c|c|c|c|c|c|}
\hline & \multicolumn{4}{|c|}{2005} & \multicolumn{4}{|c|}{1993} \\
\hline $\begin{array}{l}\text { Percentage change in } \\
\text { odd rations in India (\%) }\end{array}$ & $\begin{array}{l}\text { HH with } \\
1 \text { v.s } 0 \\
\text { children } \\
\end{array}$ & $\begin{array}{c}\text { HH with } \\
2 \text { v.s } 0 \\
\text { children }\end{array}$ & $\begin{array}{c}\text { HH with } \\
3 \text { v.s } 0 \\
\text { children }\end{array}$ & $\begin{array}{l}\text { HH with } \\
>3 \text { v.s } 0 \\
\text { children }\end{array}$ & $\begin{array}{c}\text { HH with } \\
1 \text { v.s } 0 \\
\text { children }\end{array}$ & $\begin{array}{c}\text { HH with } \\
2 \text { v.s } 0 \\
\text { children }\end{array}$ & $\begin{array}{l}\mathrm{HH} \text { with } \\
3 \mathrm{v} . \mathrm{s} 0 \\
\text { children }\end{array}$ & $\begin{array}{l}\text { HH with } \\
>3 \text { v.s } 0 \\
\text { children }\end{array}$ \\
\hline \multicolumn{9}{|l|}{ Per capita expenditure } \\
\hline Poor v.s Very poor & -18.53 & -30.29 & -41.48 & -51.02 & -12.74 & -21.21 & -30.68 & -36.45 \\
\hline Non-poor low v.s poor & -15.08 & -25.02 & -34.78 & -43.42 & -11.46 & -19.17 & -27.90 & -33.29 \\
\hline $\begin{array}{l}\text { Non-poor high v.s } \\
\text { Non-poor low }\end{array}$ & -26.57 & -41.94 & -55.39 & -65.89 & -18.52 & -30.11 & -42.33 & -49.39 \\
\hline Backward states & 7.00 & 1.94 & 37.31 & 112.46 & 0.23 & 1.35 & 12.85 & 52.72 \\
\hline Scheduled Tribe & 7.87 & 4.70 & 32.77 & 32.36 & -1.33 & -5.63 & -11.96 & -12.71 \\
\hline Scheduled Caste & -4.03 & -14.11 & -2.91 & -2.91 & -2.65 & -15.65 & -18.37 & -22.06 \\
\hline Muslim & 22.49 & 33.79 & 88.63 & 211.42 & 12.80 & 21.97 & 52.07 & 161.14 \\
\hline \multicolumn{9}{|l|}{ Average education of females } \\
\hline Literacy v.s Illiteracy & 2.73 & -2.47 & -9.24 & -17.37 & -0.65 & -5.31 & -12.37 & -17.82 \\
\hline Primary v.s Literacy & 8.43 & -7.23 & -25.23 & -43.58 & -1.94 & -15.11 & -32.72 & -44.49 \\
\hline Middle v.s Primary & 11.39 & -9.52 & -32.13 & -53.38 & -2.58 & -19.62 & -41.05 & -54.38 \\
\hline Higher secondary v.s Middle & 5.54 & -4.88 & -17.62 & -31.72 & -1.30 & -10.34 & -23.22 & -32.46 \\
\hline $\begin{array}{l}\text { University v.s Higher } \\
\text { secondary }\end{array}$ & 11.39 & -9.52 & -32.13 & -53.38 & -2.58 & -19.62 & -41.05 & -54.38 \\
\hline
\end{tabular}

Source: Computed from NSS 50th and 61st 
Table 5: Simultaneous equations

\begin{tabular}{|c|c|c|}
\hline & 1993-94 & $2004-05$ \\
\hline \multicolumn{3}{|l|}{ No. of children aged 0-14 } \\
\hline No. of females aged 15-25 & $0.221^{* * *}(0.00592)$ & $0.159^{* * *}(0.00563)$ \\
\hline No. of females aged 26-35 & $1.332^{* * *}(0.00886)$ & $1.273^{* * *}(0.00818)$ \\
\hline No. of females aged 36-49 & $0.495^{* \star *}(0.00904)$ & $0.431^{\star \star \star}(0.00840)$ \\
\hline No. of girls not in schools & $0.985^{* \star \star}(0.00818)$ & $1.046^{* \star *}(0.0108)$ \\
\hline Education of head & $0.0643^{\text {tit* }}(0.00149)$ & $0.0401^{\text {kt+ }}(0.00101)$ \\
\hline Average education level of females & $-0.0781^{*+* t}(0.00185)$ & $-0.0668^{++1+x}(0.00162)$ \\
\hline Per capita expenditure (Rupee 00) & $-0.110^{*+*}(0.00207)$ & $-0.0770^{+1+1+1}(0.00119)$ \\
\hline Per capita expenditure/100 & $0.142^{* \star *}(0.00408)$ & $0.0683^{\text {thto }}(0.00165)$ \\
\hline Health share of total expenditure & $0.00244^{* * * *}(0.000298)$ & $0.00641^{+*+1}(0.000483)$ \\
\hline Scheduled caste & $-0.0548^{* * *}(0.0116)$ & $0.0219^{* *}(0.0106)$ \\
\hline Scheduled tribe & $-0.0345^{*+\alpha}(0.0133)$ & $0.0852^{* k *}(0.0114)$ \\
\hline Muslim & $0.384^{* * *}(0.0135)$ & $0.408^{\star \star \star}(0.0121)$ \\
\hline Bihar, MP, UP, Orissa and Rajasthan & $0.197^{*+\alpha}(0.00861)$ & $0.324^{* * \star}(0.00829)$ \\
\hline Rural areas & $-0.0169^{*}(0.00921)$ & $-0.0475^{\text {t+kt }}(0.00843)$ \\
\hline Constant & $0.978^{* * \star}(0.0151)$ & $1.194^{* * *}(0.0143)$ \\
\hline \multicolumn{3}{|l|}{ No. of children in school } \\
\hline No. of children aged 0-14 & $0.612^{* * *}(0.00493)$ & $0.673^{* * *}(0.00438)$ \\
\hline Dependent ratio & $0.0529^{\text {t+*x }}(0.00257)$ & $0.0435^{*+\alpha+x}(0.00229)$ \\
\hline No. of girls not in schools & $-0.830^{*+* x}(0.00656)$ & $-0.897^{\text {t*x }}(0.00738)$ \\
\hline Education of head & $0.00938^{* * *}(0.000880)$ & $-0.00310^{* * * *}(0.000575)$ \\
\hline Average education level of females & $0.0250^{*+*+1}(0.00108)$ & $0.0206^{* k *}(0.000896)$ \\
\hline Per capita expenditure (Rupee 00) & $0.0136^{+* t+x}(0.00127)$ & $0.0111^{* * *}(0.000730)$ \\
\hline Per capita expenditure/100 & $-0.0234^{*+1+x}(0.00242)$ & $-0.0122^{*+*}(0.000965)$ \\
\hline Health share of total expenditure & $-0.00247^{\star \star *}(0.000172)$ & $-0.00552^{2+* x}(0.000271)$ \\
\hline Scheduled caste & $-0.0497^{\text {tot }}(0.00671)$ & $-0.0122^{* *}(0.00593)$ \\
\hline Scheduled tribe & $-0.0571^{\text {t*t* }}(0.00769)$ & $-0.0118^{*}(0.00647)$ \\
\hline Muslim & $-0.138^{* * t}(0.00785)$ & $-0.0847^{\text {tote }}(0.00683)$ \\
\hline Bihar, MP, UP, Orissa and Rajasthan & $-0.138^{* * *}(0.00498)$ & $-0.0982^{+*+1}(0.00473)$ \\
\hline Rural areas & $0.0170^{+* *+}(0.00533)$ & $0.0436^{+n+x}(0.00476)$ \\
\hline Constant & $-0.316^{*+\alpha}(0.00906)$ & $-0.274^{* * * *}(0.00874)$ \\
\hline Observations & 103,477 & 111,978 \\
\hline
\end{tabular}

Sources: 1. Computed from NSS 61th, 2004-05

2. Chaudhri and Jha, 'Child Poverty and Elementary Education in India', ASARC Working Paper 2011/04.

Notes: Standard errors in parentheses ${ }^{*} p<=0.10,{ }^{* *} p<=0.05,{ }^{* * *} p<=0.01$

1. At average value, estimates of elasticity multipliers w.r.t. number of Girls not in Schools is $0.096 \%$ in 1993 and $0.057 \%$ in 2005

2. At average value, estimates of elasticity multipliers w.r.t. MPCE is $-0.198 \%$ in 1993 and $-0.283 \%$ in 2005

3. At average value, estimates of elasticity multipliers w.r.t. Education level of females is $-0.109 \%$ in 1993 and $-0.130 \%$ in 2005 
Table A1: Estimates of Child Poverty using the Absolute Poverty Line in India

\begin{tabular}{|c|c|c|c|c|c|c|c|c|c|}
\hline & \multicolumn{3}{|c|}{ 2004-05 } & \multicolumn{3}{|c|}{$1993-94$} & \multicolumn{3}{|c|}{ Change (\%) } \\
\hline & $0-4$ & $5-9$ & $0-14$ & $0-4$ & $5-9$ & $0-14$ & $0-4$ & $5-9$ & $0-14$ \\
\hline $\begin{array}{l}\text { All India } \\
\text { States }\end{array}$ & 33.77 & 33.84 & 31.72 & 46.07 & 45.3 & 43.4 & -26.7 & -25.3 & -26.8 \\
\hline Andhra Pradesh & 16.23 & 18.58 & 17.67 & 31.33 & 29.38 & 27.85 & -48.2 & -36.8 & -36.6 \\
\hline Assam & 24.43 & 26.19 & 23.07 & 53.72 & 51.74 & 49.81 & -54.5 & -49.4 & -53.7 \\
\hline Bihar & 44.42 & 43.53 & 41.65 & 65.80 & 63.06 & 61.85 & -32.5 & -31.0 & -32.7 \\
\hline Dadra and Nagar Haveli & 29.56 & 32.32 & 26.47 & 64.52 & 72.07 & 64.00 & -54.2 & -55.2 & -58.6 \\
\hline Delhi & 17.43 & 15.46 & 15.89 & 22.30 & 23.46 & 20.55 & -21.9 & -34.1 & -22.7 \\
\hline Gujrat & 18.2 & 21.1 & 18.38 & 29.79 & 29.24 & 27.18 & -38.9 & -27.8 & -32.4 \\
\hline Haryana & 20.08 & 19.98 & 17.72 & 33.19 & 30.61 & 30.27 & -39.5 & -34.7 & -41.5 \\
\hline Himachal Pradesh & 12.91 & 13.27 & 12.48 & 40.17 & 35.78 & 35.27 & -67.9 & -62.9 & -64.6 \\
\hline Jammu and Kashmir & 4.816 & 5.608 & 4.838 & 21.71 & 21.62 & 20.18 & -77.8 & -74.1 & -76.0 \\
\hline Karnataka & 30.04 & 32.17 & 29.09 & 43.08 & 42.23 & 41.06 & -30.3 & -23.8 & -29.1 \\
\hline Kerala & 26.56 & 27.48 & 25.18 & 34.96 & 33.66 & 32.80 & -24.0 & -18.4 & -23.2 \\
\hline Madhya Pradesh & 42.8 & 42.48 & 40.05 & 50.92 & 49.07 & 47.78 & -15.9 & -13.4 & -16.2 \\
\hline Maharastra & 39.54 & 36.87 & 35.89 & 42.99 & 43.34 & 39.78 & -8.0 & -14.9 & -9.8 \\
\hline Orissa & 55.34 & 53.44 & 51.44 & 59.32 & 59.87 & 56.22 & -6.7 & -10.7 & -8.5 \\
\hline Punjab & 14.37 & 14.57 & 12.66 & 20.84 & 18.41 & 18.19 & -31.1 & -20.8 & -30.4 \\
\hline Rajasthan & 26.35 & 26.99 & 25.07 & 34.13 & 32.39 & 31.20 & -22.8 & -16.7 & -19.6 \\
\hline Tamil Nadu & 25.5 & 28.95 & 26.4 & 36.92 & 41.21 & 38.74 & -30.9 & -29.7 & -31.8 \\
\hline Uttar Pradesh & 37.43 & 37.45 & 35.69 & 52.48 & 51.25 & 50.11 & -28.7 & -26.9 & -28.8 \\
\hline West Bengal & 38.84 & 38.05 & 35.26 & 54.38 & 52.34 & 50.40 & -28.6 & -27.3 & -30.0 \\
\hline
\end{tabular}

Sources: 1. Computed from NSS 61st Round for 2004-05 and NSS 50th Round for 1993-94

2. Chaudhri and Jha, 'Child Poverty and Elementary Education in India', ASARC Working Paper 2011/04. 
Table A2: Total fertility rates in major states of India 1961-2001

\begin{tabular}{lccccc}
\hline States & $\mathbf{1 9 6 1}$ & $\mathbf{1 9 7 1}$ & $\mathbf{1 9 8 1}$ & $\mathbf{1 9 9 1}$ & $\mathbf{2 0 0 1}$ \\
\hline Andhra Pradesh & 4.6 & 4.6 & 4.0 & 2.8 & 2.1 \\
Bihar & 7.9 & 5.6 & 5.7 & 4.6 & 3.9 \\
Jharkhand & 7.9 & 5.6 & 5.7 & 4.6 & 3.3 \\
Gujarat & 7.1 & 5.6 & 4.3 & 3.2 & 2.6 \\
Haryana & 8.9 & 6.7 & 5.0 & 3.8 & 2.8 \\
Himachal Pradesh & 6.7 & 5.2 & 3.8 & 3.1 & 2.1 \\
Karnataka & 5.3 & 4.4 & 3.6 & 2.9 & 2.2 \\
Kerala & 5.6 & 4.1 & 2.8 & 1.7 & 1.8 \\
Madhya Pradesh & 5.6 & 5.6 & 5.2 & 4.4 & 3.7 \\
Chhattisgarh & 5.6 & 5.6 & 5.2 & 4.4 & 3.3 \\
Maharashtra & 5.9 & 4.6 & 3.6 & 2.9 & 2.4 \\
Orissa & 4.3 & 4.7 & 4.3 & 3.1 & 2.5 \\
Punjab & 6.7 & 5.2 & 4.0 & 3.1 & 2.3 \\
Rajasthan & 6.6 & 6.2 & 5.2 & 4.5 & 3.6 \\
Tamil Nadu & 3.7 & 3.9 & 3.4 & 2.2 & 1.9 \\
Uttar Pradesh & 7.6 & 6.6 & 5.8 & 5.2 & 4.4 \\
Uttaranchal & 7.6 & 6.6 & 5.8 & 5.2 & 3.2 \\
West Bengal & 6.8 & 5.4 & 4.2 & 2.9 & 2.2 \\
\hline All India & 6.1 & 6.5 & 5.4 & 4.6 & $\mathbf{2 . 9}$ \\
\hline
\end{tabular}

Sources: 1. Census of India 1961, 1971, 1981, 1991 and 2001

2. Ron C. Mittelhammer, Tauhidur Rahman (2004), Distribution of Human Development, Child Labor and Poverty in India.

3. National Commission on Population MHFW 2006

4. Chaudhri and Jha 2011d, 'Child Poverty and Elementary Education in India', ASARC Working Paper 2011/04. 
Table A3: Household size, number of children (0-14) in poor and non poor households in India

\begin{tabular}{|c|c|c|c|c|c|c|c|c|}
\hline & \multicolumn{4}{|c|}{$2004-05$} & \multicolumn{4}{|c|}{$1993-14$} \\
\hline & $\begin{array}{l}\text { Very } \\
\text { poor }\end{array}$ & $\begin{array}{c}\text { Moderately } \\
\text { poor }\end{array}$ & $\begin{array}{c}\text { Non-poor } \\
\text { low }\end{array}$ & $\begin{array}{c}\text { Non-poor } \\
\text { high }\end{array}$ & $\begin{array}{l}\text { Very } \\
\text { poor }\end{array}$ & $\begin{array}{c}\text { Moderately } \\
\text { poor }\end{array}$ & $\begin{array}{c}\text { Non-poor } \\
\text { low }\end{array}$ & $\begin{array}{c}\text { Non-poor } \\
\text { high }\end{array}$ \\
\hline Family size* & 5.5 & 5.8 & 5.1 & 3.9 & 5.8 & 5.6 & 5.0 & 3.9 \\
\hline Children+ & 2.6 & 2.4 & 1.7 & 0.9 & 2.9 & 2.4 & 1.7 & 1.0 \\
\hline Adults & 2.9 & 3.4 & 3.4 & 3.0 & 2.9 & 3.2 & 3.3 & 2.9 \\
\hline
\end{tabular}

Sources: 1. Computed from NSS 61st Round for 2004-05 and NSS 50th Round for 1993-94

2. 'Poverty estimates for 2004-05', Press Information Bureau of Government of India, New Delhi, March-2007

3. Savita Sarma, 'Poverty Estimates in India: Some key issues', ERD Working Paper Series No. 51, ADB, May 2004.

4. Chaudhri and Jha, 'Child Poverty and Elementary Education in India', ASARC Working Paper 2011/04.

* all paimise comparisons of differences in mean values of household size are statistically significant at 1\% within the two samples and also between 1993-94 and 2004-05 + all painise comparisons of differences in mean values of number of children are statistically significant at 1\% within the two samples and also between 1993-94 and 2004-05 